\title{
Correction: The PARP inhibitor olaparib enhances the sensitivity of Ewing sarcoma to trabectedin
}

José Luis Ordóñez, Ana Teresa Amaral, Angel M. Carcaboso, David Herrero-Martín, María del Carmen García-Macías, Vicky Sevillano, Diego Alonso, Guillem PascualPasto, Laura San-Segundo, Monica Vila-Ubach, Telmo Rodrigues, Susana Fraile, Cristina Teodosio, Agustín Mayo-Iscar, Miguel Aracil, Carlos María Galmarini, Oscar M. Tirado, Jaume Mora and Enrique de Álava

Copyright: Luis Ordóñez et al. This is an open-access article distributed under the terms of the Creative Commons Attribution License 3.0 (CC BY 3.0), which permits unrestricted use, distribution, and reproduction in any medium, provided the original author and source are credited.

Present: The published funding information is incomplete.

Correct: Additional funding information is given below.

\section{FUNDING}

This project has received funding from the European Union's Seventh Framework Programme for research, technological development and demonstration under grant agreement nr 602856 (EEC) and nr 278742 (EUROSARC).

Original article: Oncotarget. 2015; 6:18875-90. doi: 10.18632/oncotarget.4303 